\title{
Seroprevalence of Brucellosis in sheep and goats in Duhok and Sumel districts of northern Iraq
}

\author{
Nazik Mahmood Ilyas \\ University of Duhok, Basic Education College, \\ Science Department, PO Box 78, Duhok, Iraq \\ E-mail: nazkxp@gmail.com \\ Ferda Karakus (Corresponding author) \\ Van Yuzuncu Yil University, Faculty of Agriculture, \\ Department of Animal Science, 65080 Van, Turkey \\ E-mail: fkarakus@yyu.edu.tr
}

\begin{abstract}
The aim of this study was to determine the seroprevalence of brucellosis in sheep and goat herds in Duhok and Sumel districts of northern Iraq. A total of 600 serum samples (400 sheep and 200 goats) were used and screened for brucellosis by serological method indirect ELISA test. The number of seropositive animals determined in Duhok was 12 (6.0\%) and 7 (7.0\%) for sheep and goats, respectively. Brucella was positive in 19 out of 300 animals, together with an overall animal level seroprevalence of $6.3 \%$. The number of brucellosis seropositive animals in Sumel was found $15(7.5 \%)$ and $7(7.0 \%)$ for sheep and goats, respectively. Seroprevalence of brucellosis at an overall animal level was found to be $7.3 \%$. In this study, brucella was positive in 41 out of 600 sheep and goat sera. The results showed that seroprevalence of brucellosis was $6.75 \%(27 / 400)$ for sheep and $7.0 \%$ (14/200) for goats. Systematic investigations should be conducted in these study areas in order to accurately evaluate the prevalence of brucellosis and to effectively implement eradication strategies.
\end{abstract}

Keywords: Brucella, Sheep, Goat, Seroprevalence, ELISA

DOI: $10.7176 / J S T R / 5-11-06$

\section{Introduction}

Although small ruminants are of great importance in the livelihood of producers, the productivity of sheep and goats in developing countries remains low because of inadequate feeding, poor management systems and diseases. Brucellosis is one of the most restrictive infectious diseases in sheep and goat production (Alemneh and Akeberegn, 2018).

According to the Food and Agriculture Organization (FAO), the World Health Organization (WHO) and the Office International des Epizooties (OIE), brucellosis is still one of the most important and widespread zoonoses in the world (Lopes et al., 2010). Brucellosis is a source of economic concern in many parts of the world due to reduced productivity, abortions, weak offspring and significant barriers to livestock trade and exports (Bano and Lone, 2015).

Brucellosis is a highly infectious, chronic disease in livestock and humans caused by Brucella bacteria (FAO, 2018). Brucella melitensis, B. abortus, B. suis and B. ovis infect small ruminants, cattle, pigs and sheep, respectively (Franc et al., 2018). Except for B. ovis, all of Brucella spp. has zoonotic potential, with B. melitensis being the most pathogenic for humans (Poester et al., 2013).

Risk factors for brucellosis seroprevalence of sheep and goat flocks were reported as breed, contact with other animals (cattle, sheep, goats, others), frequency of disinfecting practices (per year), animals incorporated to the flock during the previous year, membership in a farmers animal-health organisation, feeding, type of grazing, mate control, origin of the farm, and trashumance (Reviriego et al., 2000). Primatika et al. (2016) reported that some risk factors for Brucella infection of small ruminants included large herd size, high animal density, lack of corral hygiene, keeping sheep in addition to goats, uncontrolled animal movements, shared communal pastures, and intermingling of herds.

Small ruminants are considered the main source of human infection (Primatika et al., 2016). Jaff (2016) reported that the prevalence and incidence of human brucellosis in Iraq was still high. Therefore, it is 
important to determine the prevalence of brucellosis and possible risk factors in small ruminants in this region, and thus to provide solutions for eradication of the disease. The aim of this study was to determine the seroprevalence of brucellosis in sheep and goat herds in Duhok and Sumel districts of northern Iraq.

\section{Material and Methods}

\subsection{Study area and collection of samples}

Study was carried out in the districts of Duhok and Sumel in northern Iraq. Sumel is about 20 kilometers west of the provincial capital of Duhok (Dosky, 2012). There are about a million head of sheep and goats in Duhok. Sheep and goats are grazed separately or together under the common grazing system in Duhok, which has a wide pasture area (Alhamada et al., 2017).

Five farms with at least 100 head sheep and 50 head goats were selected in each district. Forty sheep and 20 goats from each farm were randomly selected as study material. Approximately $10 \mathrm{ml}$ of blood was collected from the jugular vein of each animal, labeled and transported to the Veterinary Directorate of Duhok. Samples were collected from non-vaccinated animals.

\subsection{Serological analyses}

Blood samples stored immediately at $4{ }^{\circ} \mathrm{C}$ were centrifuged for 10 minutes at $3000 \mathrm{rpm}$ and the sera were stored at $-20{ }^{\circ} \mathrm{C}$ until tested. All serum samples were screened for brucellosis by serological method indirect ELISA test. Serum obtained from sheep and goats were tested for anti-Brucella IgG antibodies using ELISA kits according to the manufacturer's instructions. Serum was considered serologically positive when a positive result was recorded on the test (Alhamada et al., 2017). The percentage of seropositive animals against the total number of animals tested was determined (Polak and Zmudzinski, 1999).

Data were entered into Microsoft Office Excel 2016 and frequency analyses were performed SPSS version 20 (SPSS Inc., Chicago IL, USA).

\section{Results}

Population size and the number of seropositive animals according to farms in Duhok and Sumel are shown in Table 1 and Table 2. The number of seropositive animals determined in sheep and goats in the farms studied in Duhok were 4, 4, 3, 2, and 6, respectively, while the farms in Sumel were 5, 7, 5, 2, and 3 , respectively.

In the study, a total of 600 serum samples (400 sheep and 200 goats) were used for detection of Brucella. Seroprevalence of brucellosis according to animal species in Duhok and Sumel are shown in Table 3. The number of seropositive animals determined in Duhok was $12(6.0 \%)$ and 7 (7.0\%) for sheep and goats, respectively. Brucella was positive in 19 out of 300 animals, together with an overall animal level seroprevalence of $6.3 \%$.

As shown in Table 3, the number of brucellosis seropositive animals in Sumel was found 15 (7.5\%) and 7 (7.0\%) for sheep and goats, respectively. A total of 22 animals were serologically positive in this district. Seroprevalence of brucellosis at an overall animal level was found to be $7.3 \%$.

Table 1. Population size and the number of seropositive animals according to farms in Duhok

\begin{tabular}{lccccccc}
\hline \multirow{2}{*}{ Farm no } & \multicolumn{2}{c}{$\begin{array}{c}\text { Total population } \\
\text { (heads) }\end{array}$} & \multicolumn{2}{c}{$\begin{array}{c}\text { Tested animals } \\
\text { (heads) }\end{array}$} & \multicolumn{3}{c}{$\begin{array}{c}\text { Seropositive animals } \\
\text { n (\%) }\end{array}$} \\
\cline { 2 - 7 } & Sheep & Goat & Sheep & Goat & Total & Sheep & Goat \\
\cline { 2 - 7 } 1 & 135 & 65 & 40 & 20 & $4(6.7 \%)$ & $2(5.0 \%)$ & $2(10.0 \%)$ \\
2 & 300 & 100 & 40 & 20 & $4(6.7 \%)$ & $3(7.5 \%)$ & $1(5.0 \%)$ \\
3 & 622 & 78 & 40 & 20 & $3(5.0 \%)$ & $3(7.5 \%)$ & 0 \\
4 & 332 & 105 & 40 & 20 & $2(3.3 \%)$ & 0 & $2(10.0 \%)$ \\
5 & 280 & 120 & 40 & 20 & $6(10.0 \%)$ & $4(10.0 \%)$ & $2(10.0 \%)$ \\
\hline
\end{tabular}


Table 2. Population size and the number of seropositive animals according to farms in Sumel

\begin{tabular}{lccccccc}
\hline \multirow{2}{*}{ Farm no } & \multicolumn{2}{c}{$\begin{array}{c}\text { Total population } \\
\text { (heads) }\end{array}$} & \multicolumn{2}{c}{$\begin{array}{c}\text { Tested animals } \\
\text { (heads) }\end{array}$} & \multicolumn{3}{c}{$\begin{array}{c}\text { Seropositive animals } \\
\text { n (\%) }\end{array}$} \\
\cline { 2 - 8 } & Sheep & Goat & Sheep & Goat & Total & Sheep & Goat \\
\cline { 2 - 8 } 1 & 335 & 95 & 40 & 20 & $5(8.3 \%)$ & $3(7.5 \%)$ & $2(10.0 \%)$ \\
2 & 140 & 110 & 40 & 20 & $7(11.7 \%)$ & $7(17.5 \%)$ & 0 \\
3 & 314 & 86 & 40 & 20 & $5(8.3 \%)$ & $1(2.5 \%)$ & $4(20.0 \%)$ \\
4 & 420 & 100 & 40 & 20 & $2(3.3 \%)$ & $2(5.0 \%)$ & 0 \\
5 & 584 & 180 & 40 & 20 & $3(5.0 \%)$ & $2(5.0 \%)$ & $1(5.0 \%)$ \\
\hline
\end{tabular}

Table 3. Seroprevalence of brucellosis in sheep and goats in Duhok and Sumel districts

\begin{tabular}{|c|c|c|c|c|c|c|}
\hline \multirow[b]{2}{*}{ District } & \multirow[b]{2}{*}{ Species } & \multirow{2}{*}{$\begin{array}{l}\text { Tested animals } \\
\text { (heads) }\end{array}$} & \multicolumn{2}{|c|}{ Positive cases } & \multicolumn{2}{|c|}{ Negative cases } \\
\hline & & & Number & $\%$ & Number & $\%$ \\
\hline \multirow[t]{3}{*}{ Duhok } & Sheep & 200 & 12 & 6.0 & 188 & 94.0 \\
\hline & Goat & 100 & 7 & 7.0 & 93 & 93.0 \\
\hline & Overall & 300 & 19 & 6.3 & 281 & 93.7 \\
\hline \multirow[t]{3}{*}{ Sumel } & Sheep & 200 & 15 & 7.5 & 185 & 92.5 \\
\hline & Goat & 100 & 7 & 7.0 & 93 & 93.0 \\
\hline & Overall & 300 & 22 & 7.3 & 278 & 92.7 \\
\hline
\end{tabular}

\section{Discussion}

In this study, brucella was positive in 41 out of 600 sheep and goat sera. The results showed that seroprevalence of brucellosis was 6.75\% (27/400) for sheep and 7.0\% (14/200) for goats. Contrary to the findings of this study, Ljung (2013) and Rajala et al. (2016) revealed that brucella was more prevalent in sheep than goats. Whereas, Sintayehu et al. (2015) reported that goats were about four times more likely to be infected than sheep. Franc et al. (2018) reported an average prevalence ranging from $0 \%$ to $88.8 \%$ in sheep and goats in Africa and Asia.

Seropositivity values of $6.0 \%$ and $7.5 \%$ for sheep herds in Duhok and Sumel were higher than the values reported as $0.7 \%$ by Reviriego et al. (2000) in Spain, $0.9 \%$ by Mokhtar et al. (2007) in eastern Sudan, $0.8 \%$ by Sintayehu et al. (2015) in Ethiopia, and $0.9 \%$ by Lakew et al. (2019) in Ehiopian-Somali pastoral communities. On the other hand, when compared with the findings of this study, higher seropositivity values for sheep was reported by Al-Majali et al. (2007) in southern Jordan (37.6\%), Așkar et al. (2013) in Turkey (13.5\%), Gholizadeh et al. (2013) in Iran (31.7\%), Rajala et al. (2016) in Tajikistan (11\%), AlGriw et al. (2017) in north west Libya (9.2\%), and Al-Busultan et al. (2018) in Iraq (57.94\%). In addition, higher seroprevalence for sheep (31\%) in Duhok, Iraq were reported by Alhamada et al. (2017).

In this study, the $7.0 \%$ seropositive value of goat herds was found to be lower than $34 \%$ reported by Gholizadeh et al. (2013) in Iran, and the values reported by Al-Busultan et al. (2018) as 62.5\% and Alhamada et al. (2017) as 34\% in Iraq. However, compared with the findings of this study, lower seroprevalence rates of brucellosis were reported for goat herds in eastern Sudan (Mokhtar et al., 2007), Ethiopia (Dabassa et al., 2013; Sintayehu et al., 2015), Tajikistan (Ljung, 2013; Rajala et al., 2016), and north west Libya (Al-Griw et al., 2017).

The overall seroprevalence of sheep and goat brucellosis recorded in Duhok $(6.3 \%, 19 / 300)$ and Sumel $(7.3 \%, 22 / 300)$ was lower than total prevalence value $(59.5 \%, 97 / 163)$ reported by Al-Busultan et al. (2018) in Iraq, but higher than those $(2.34 \%, 9 / 384$ and $1.56 \%, 6 / 384)$ reported by Dabassa et al. (2013) in Ethiopia. On the other hand, prevalence of Brucella determined by Salih (2010) as 6.51\% in sheep and goats in Iraq was consistent with the findings of the study. Variations observed in brucellosis seroprevalence studies might occur due to agro-ecological differences of study areas, sample size, animal management, diagnostic test used and production systems (Lakew et al., 2019).

\section{Conclusion}

In conclusion, this study showed the seroprevalence of Brucella in sheep and goats reared in Duhok and Sumel districts of northern Iraq. There are not many studies showing the prevalence of brucellosis in these regions, so that no studies have been conducted in the Sumel region. The seroprevalence of ovine 
and caprine brucellosis have been studied in different countries of the world. Al-Busultan et al. (2018) reported that the prevalence of brucellosis varies not only between countries but also within countries, and that demographic, occupational, cultural and socioeconomic factors may play an important role in this variation. Brucellosis is a significant productivity and reproductivity problem in small ruminants. It is useful to improve the control and prevention methods by considering the possible risk factors to reduce economic losses occuring due to brucellosis in sheep and goat herds. Systematic investigations should be conducted in these study areas in order to accurately evaluate the prevalence of brucellosis and to effectively implement eradication strategies.

\section{References}

Al-Busultan, A.S., Al-Bassam, L.S, Al-Shididi, A.M., Al-Hashemi, B.M. 2018. Cross sectional study on the seroprevalence of brucellosis in sheep, goat and man in Diyala governorate. Mirror of Research in Veterinary Sciences and Animals, 7(1), 1-19.

Al-Griw, H.H., Elfurgani, S.K., Farhat, M.E., Perrett, L.L., Whatmore, A.M. 2017. Evidence of ongoing brucellosis in livestock animals in North West Libya. Journal of Epidemiology and Global Health, 7, 285-288.

Al-Majali, A.M., Majok, A.A., Amarin, N.M., Al-Rawashdeh, O.F. 2007. Prevalence of, and risk factors for, brucellosis in Awassi sheep in Southern Jordan. Small Ruminant Research, 73, 300303.

Alemneh, T., Akeberegn, D. 2018. A review on small ruminants brucellosis. Global Journal of Medical Research: G Veterinary Science and Veterinary Medicine, 18(2), 41-54.

Alhamada, A.G., Habib, I., Barnes, A., Robertson, I. 2017. Risk factors associated with brucella seropositivity in sheep and goats in Duhok province, Iraq. Veterinary Science, 4(65), 1-9.

Aşkar, Ş., Mumcu, F., Ünal, N., Yildirim, M. 2013. Kırıkkale ve yöresindeki süt sığırı ve koyunlar ile bunların yetiştiricilerinde brucella antikoru varlığının araştırılması. YYU Veteriner Fakültesi Dergisi, 24(3), 113-116.

Bano, Y., Lone, S.A. 2015. Brucellosis: An economically important infection. Journal of Medical Microbiology and Diagnosis, 4(4), 1-8.

Dabassa, G., Tefera, M., Addis, M. 2013. Small ruminant brucellosis: serological survey in Yabello District, Ethiopia. Asian Journal of Animal Sciences, 7(1), 14-21.

Dosky, A.K. 2012. The great goat flood refugee livestock causing crisis in Dohuk. [Online] Available: https://www.niqash.org/en/articles/economy/3102/ (November 10, 2019).

FAO. 2018. Africa sustainable livestock 2050. Zoonotic diseases spotlight Egypt. The case for an expert elicitation protocol on zoonoses, 8p.

Franc, K.A., Krecek, R.C., Hasler, B.N., Arenas-Gamboa, A.M. 2018. Brucellosis remains a neglected disease in the developing world: a call for interdisciplinary action. BMC Public Health, $18,1-9$.

Gholizadeh, S.S., Zali, M.H.S., Hashempour, A., Ahmadi, E.M. 2013. Investigation of brucellosis in cattle and sheep in Urmia - Iran. YYU Veteriner Fakültesi Dergisi, 24(3), 133-134.

Jaff, D. 2016. Brucellosis in Iraqi Kurdistan: An overview. Journal of Entomology and Zoology Studies, 4(4), 1113-1115.

Lakew, A., Hiko, A., Abraha, A., Hailu, S.M. 2019. Sero-prevalence and community awareness on the risks associated with Livestock and Human brucellosis in selected districts of Fafan Zone of Ethiopian-Somali National Regional State. Veterinary and Animal Science, 7(2019), 1000473. 
Ljung, I. 2013. Brucellosis in small ruminants - a seroprevalence study in peri-urban farming around the region of Dushanbe, Tajikistan. Sveriges lantbruksuniversitet, Fakulteten för veterinärmedicin och husdjursvetenskap Institutionen för kliniska vetenskaper, 40, 1-23.

Lopes, L.B., Nicolino, R. and Haddad, J.P.A. 2010. Brucellosis - risk factors and prevalence: A review. The Open Veterinary Science Journal, 4, 72-84.

Mokhtar, M.O., Abdelaziz, A.A., Abusalab, S.M.A., Ahmed, A.M. 2007. Survey of brucellosis among sheep, goats, camels and cattle in Kassala area, eastern Sudan. Journal of Animal and Veterinary Advances, 6(5), 635-637.

Poester, F.P., Samartino, L.E., Santos, R.L. 2013. Pathogenesis and pathobiology of brucellosis in livestock. Scientific and Technical Review of the Office International des Epizooties, 32(1), 105115.

Polak, M.P., Zmudzinski, J.F. 1999. Prevalence of bovine viral diarrhea virus (BVDV) infection in cattle in Poland. Bulletin of the Veterinary Institute in Pulawy, 43, 107-111.

Primatika, R.A., Nugroho, W.S., Septana, A.I. 2016. Survey of brucellosis in goats using Rose Bengal Test (RBT) and Complement Fixation Test (CFT) methods in Gunungkidul district, special region of Yogyakarta, Indonesia. Advances of Science and Technology for Society AIP Conference Proceedings, 1755.

Reviriego, F.J., Moreno, M.A., Dominguez, L. 2000. Risk factors for brucellosis seroprevalence of sheep and goat flocks in Spain. Preventive Veterinary Medicine, 44, 167-173.

Rajala, E.L., Grahn, C., Ljung, I., Sattorov, N., Boqvist, S., Magnusson, U. 2016. Prevalence and risk factors for Brucella seropositivity among sheep and goats in a peri-urban region of Tajikistan. Tropical Animal Health and Production, 48, 553-558.

Salih, H.M.S. 2010. Brucellosis in Iraq: epidemiology, present status, and challenges in controlling the disease. Ms. Thesis, Kansas State University, Manhattan, Kansas.

Sintayehu, G., Melesse, B., Abayneh, D., Sintayehu, A., Melaku, S., Alehegne, W., Mesfin, S., De Blas, I., Casal, J., Allepuz, A., Martin-Valls, G., Africa, T., Abera, K. 2015. Epidemiological survey of brucellosis in sheep and goats in selected pastoral and agro-pastoral lowlands of Ethiopia. Revue Scientifique et Technique, 34(3), 881-893. 